УДК 94 «1914/1917»:32.019.51

DOI: https://doi.org/10.31470/2518-7600-2021-13-208-228

POSTERS AND LEAFLETS IN PROPAGANDA OF WAR LOANS IN THE RUSSIAN EMPIRE DURING THE FIRST WORLD WAR

\title{
ПЛАКАТИ І ЛИСТІВКИ У ПРОПАГАНДІ ОБЛІГАЦІЙ ВІЙСЬКОВИХ ПОЗИК В РОСІЙСЬКІЙ ІМПЕРІЇ В РОКИ ПЕРШОЇ СВІТОВОЇ ВІЙНИ
}

\section{ПЛАКАТЫ И ОТКРЫТКИ В ПРОПАГАНДЕ ОБЛИГАЦИЙ ВОЕННЫХ ЗАЙМОВ В РОССИЙСКОЙ ИМПЕРИИ В ГОДЫ ПЕРВОЙ МИРОВОЙ ВОЙНЫ}

\section{Світлана Орлик,}

доктор історичних наук, професор, професор кафедри історії, археологіï, інформаційної та архівної справи svitlana.orlik@gmail.com ORCID: 0000-0002-6280-9273 Researcher ID: C-1033-2019 Центральноукраїнський національний технічний університет, пр. Університетський, 8, м. Кропивницький, Україна, 25006
Svitlana Orlyk,

Ph.D. hab. in Historical sciences, Professor, Professor of Department of History, Archeology, Informational and Archival Affairs svitlana.orlik@gmail.com ORCID:0000-0002-6280-9273 Researcher ID: C-1033-2019 Central Ukrainian National Technical University, 8, Prospekt Universytetsky, Kropyvnytskyi, Ukraine, 25006

\section{ABSTRACT}

The article considers the use of visual campaign materials in the form of posters and leaflets, which were created and distributed 
among the population for the purpose of agitating and propaganda of war loans in the Russian Empire during the First World War.

The attention was drawn to the fact that printed products and periodical press were the primary means of propagandist impact, because cinema and radio have not yet become widespread. However, the production of posters and leaflets was one of the most efficient way to influence the addressee directly and comprehensively, since there were used verbal and non-verbal elements, which constitute unified visual, content, structural and functional integrity.

Attention is focused on the fact, that the practice of using propaganda posters was widely used not only in the Russian Empire, but also among other countries participating in the Great War (France, Germany, Austria-Hungary and others), which also conducted issuance of domestic government loan bonds in their countries.

The analysis of images and inscription on the posters concerning war loans subject showed, that they had purely propagandistic character and campaign direction. Famous artists were involved in the development of propaganda posters. Most poster authors' chose a realistic or nationally romantic style to enhance the effect of visualizing the problem.

The author had reached the conclusion that the use of poster art by the government of the Russian Empire and Provisional Government during promotional actions of domestic loan bonds issue, which were aimed at solving the problem of attracting financial resources for the First World War participation was extremely relevant and effective. Since the establishment of visual communication with potential buyers of these bonds by distribution of thematic posters and leaflets made it possible to carry out effective campaigning and propaganda in order to form public opinion and public actions in the interests of the government.

Keywords: First World War, Russian Empire, propaganda, campaign, war loan, bond, posters and leaflets. 
Постановка проблеми й актуальність дослідження. На початок 1914 року Російська імперія мала значні державні борги, які складали станом на 1.01.1914 р. - 8,8 млрд. руб. і на 31.12.1914 р. - 10,5 млрд. руб.. У тому числі внутрішні запозичення, за різними підрахунками, складали від 4-х до 6 млрд. руб. за курсом 1914 р. Значні потреби у фінансових ресурсах під час війни ставили перед імперським урядом завдання постійного пошуку джерел їхнього поповнення. Всього, з другої половини 1914 р. до початку 1917 р., на військові потреби було витрачено біля 25 млрд. руб. Питання де взяти гроші для війни? - для уряду Російської імперії було актуальним і невідкладним. Тож, випуск облігацій внутрішніх держаних позик стало одним із способів скорочення бюджетного дефіциту. 3 метою проведення активної агітації серед потенційних покупців облігацій імперським урядом застосовувалися різні заходи та методи розповсюдження інформації із застосуванням широкого спектру PR-технологій. У цьому напрямку особливо широко використовувалося плакатне мистецтво, яке мало відверто пропагандистський характер.

Мета статті - розглянути i продемонструвати застосування наглядних агітаційних матеріалів у вигляді плакатів та листівок у пропаганді облігацій військових позик, які здійснювалися у Російській імперії в роки Першої світової війни.

Аналіз основних досліджень. PR-технології, які застосовувалися у період Першої світової війни, стали предметом дослідження зарубіжних учених у перші роки після завершення Першої світової війни. Це праці Кемпбела Стюарта «Таємниці будинку Крю» (Stuart, 1920), Гарольда Ласвеля «Техніка пропаганди в світовій війні» (Lasswell, 1927; Ласвель, 1929). Дана проблема актуальна і для сучасних науковців, котрі досліджують різні складові проблеми агітації та пропаганди у часи міжнародних військових конфліктів, у тому числі й Першої світової війни. Це праці О. Бугрова (Бугров \& 
Татаринов, 2011), Н. Большакової (Большакова, 2006), M. Волковського (Волковский, 2003), Ж. Гольштейна (Goldstein, 2001), М. Кондратюка (Кондратюк, 2013), Г. Малишевої (Малышева, 2009), О. Мосієнка (Мосієнко, 2016), С. Орлик (Орлик, 2018; Орлик, 2020), Д.Циклакова (Цыклаков, 2012) та ін.

Виклад основного матеріалу. Традиційно виділялися три основних джерела для забезпечення військових витрат, а саме: податки, позики і випуск нових грошей. Імперський уряд, розраховуючи на короткостроковість війни, вважав першочерговим простим способом покриття військових витрат випуск (емісію) нових кредитних грошей (білетів), а потім (у мирний час) сподівався виправити ситуацію стабілізаційними заходами. Проте війна затягнулася, випуск грошей призвів до галопуючої інфляції (з другої половини 1915 р.), податковий ресурс вичерпався - підвищено існуючі та введено нові податки ще на початку війни (друга половина 1914 р. - перша половина 1915 р), і в 1916 році залишався один «рятівний круг» - випуск облігацій внутрішніх державних позик. До кінця другого року війни всім стало очевидно, що війна затягується, фінансові витрати на війну непомірно збільшувалися. На засіданні Державної Думи у лютому 1916 р. міністр фінансів П.Л. Барк зазначав: «наши расходы на войну, составлявшие в начале войны около 8 милл. в день, достигли к концу 1915 г. - 31 милл. р. в день, т.е. около 1,3 милл.р. в час» (Михайлов, 1917:80). А тому урядом було прийнято рішення про збільшення сум випусків облігацій 3 одномільярдних розмірів 1914 р. та 1915 р. до 2-х і 3-х мільярдних у 1916 p.

Для успішної реалізації програми внутрішніх військових позик потрібне було активне залучення населення до їхньої підписки, що зобов'язувало імперський уряд більше уваги приділяти масово-роз'яснювальній роботі та популяризації їхнього значення. При цьому всі ці заходи супроводжувалися потужним пропагандистським пресингом, який мав би 
базуватися на патріотичних настроях населення. Гароль Ласвель цілком слушно наголошував, що «під час війни на пропаганду може бути покладено багато завдань, наприклад: сприяння економії в їжі, мануфактурі, паливі та інших предметах; заохочення до купівлі позик, до запису у добровольці, до участі у догляді за пораненими, до вступу на службу військової промисловості тощо» (Ласвель, 1929:28).

Міністерством фінансів було підготовлено ряд брошур (деякі із залученням авторитетних науковців), листівок, плакатів про військові позики (Рис. 1).
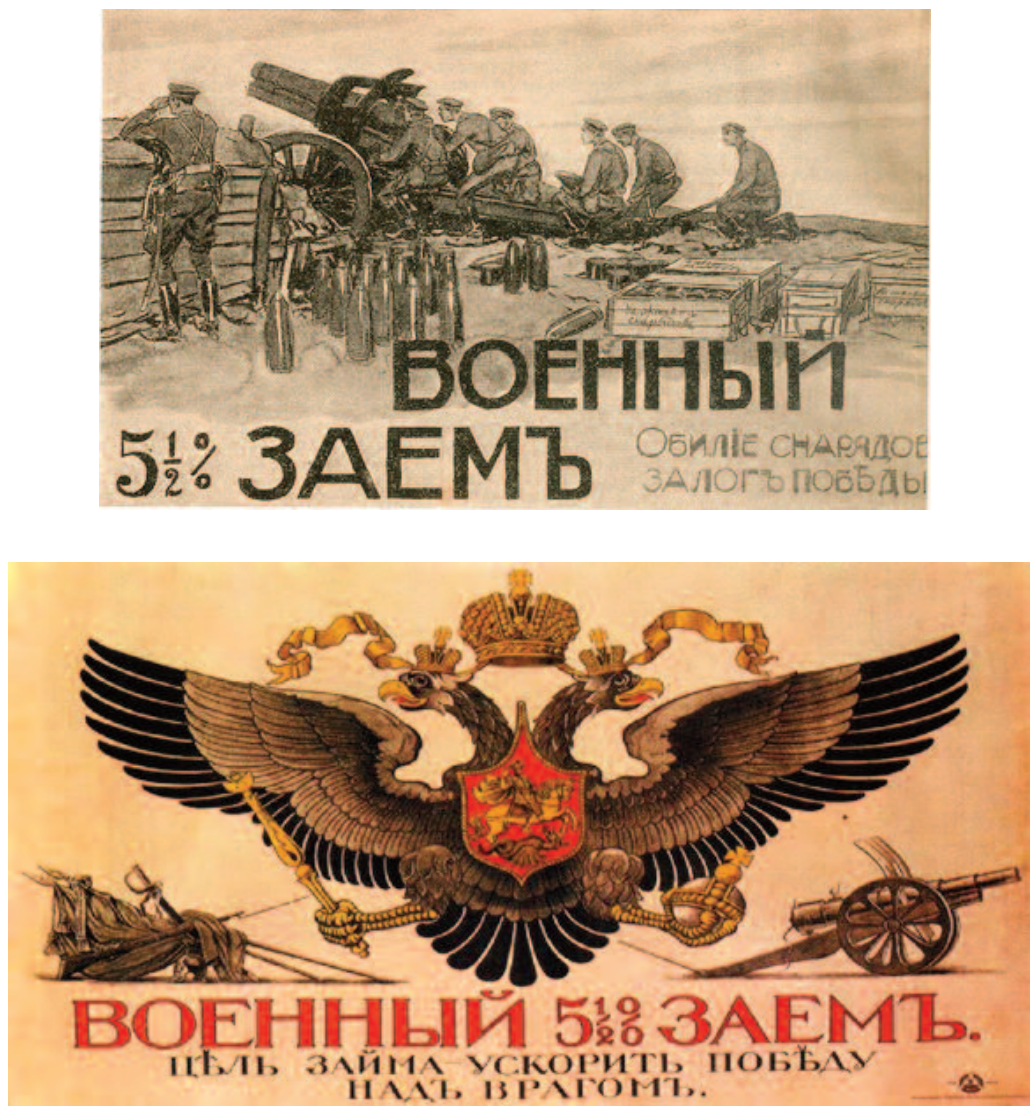

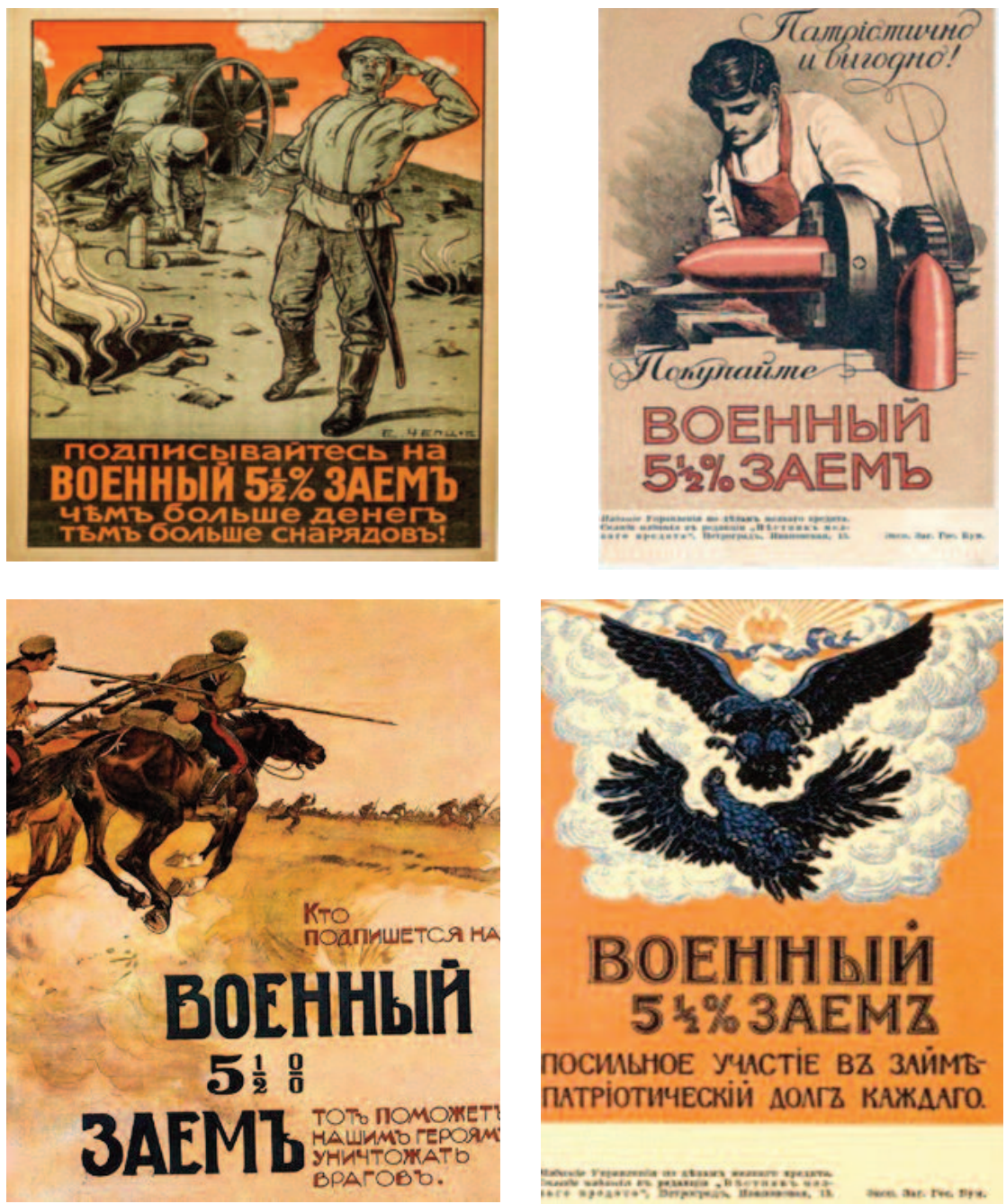

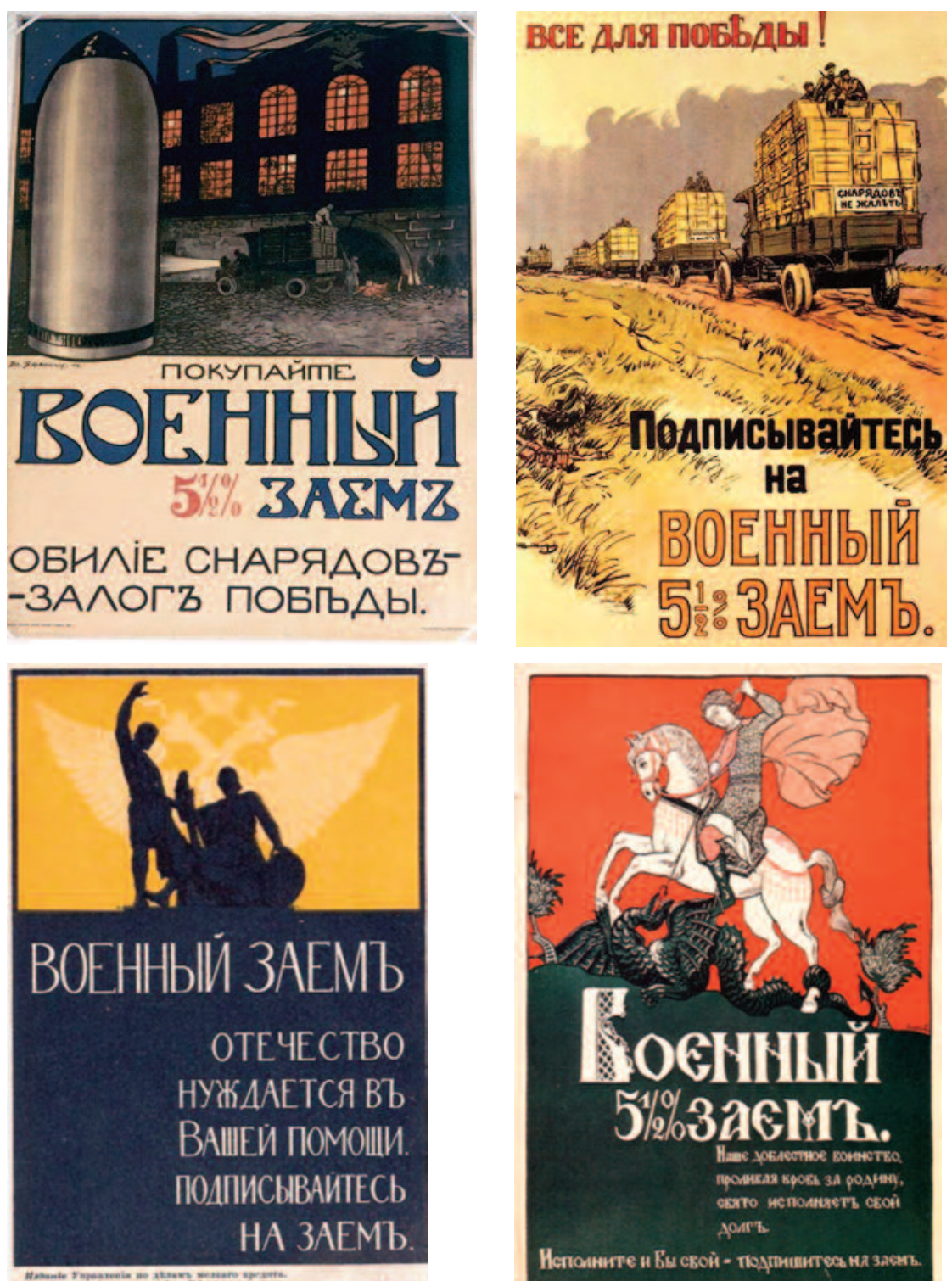

Рис. 1. Асімаційні плакати щцоо популяризацї серед населення державних військових позик 1914-1916 рр. 
Постійно друкувалися оголошення в газетах (Орлик, 2020). 3 метою наглядної популяризації серед населення державних військових позик, за замовленням Міністерства фінансів, товариством «Русской ленты В.С. Глаголина» було виготовлено агітаційні кіноп’єси «Заветная кубышка» (у 2-х частинах) i «Всё для войны» (Подписка.., 1916:2), які демонструвалися в різних містах і населених пунктах імперії.

Проте все ж у часи Першої світової війни поліграфічна продукція була основним видом пропагандистського впливу, адже кіно ще не набуло широкого поширення, «радіо ще не стало засобом масового зв'язку, а гучномовні установки були дуже примітивні й за своєю ефективністю лише трохи відрізнялися від рупорів» (Історія .., 2012:65).

У тогочасній пропагандистській діяльності досить популярним було використання плакатів. Серед сучасних науковців немає єдиного визначення терміну «плакат», проте, на нашу думку, досить комплексним $\epsilon$ визначення, запропоноване П. Скрипником, котрий вважає, що «плакат варто віднести до комбінованих текстів - складного текстового утворення, у якому вербальні й невербальні елементи становлять єдину візуальну, структурну, смислову та функціональну цілісність, спрямовану на комплексний вплив на адресата» (Скрипник, 2021:139). Плакати поділяються за типами (шрифтовий плакат, плакат із поєднанням шрифту i графічного зображення та плакати лише із графічним зображенням) та видами (пропагандистські, рекламні, соціальні, культурологічні та навчально-інструктивні). У роки Першої світової війни, як і під час інших військових конфліктів, особливо поширеними були саме пропагандистські плакати, які мають «два підвиди: агітаційний та політичний» (Андрейканіч, 2013:124). Щодо плакатів на тему військових позик, то вони були агітаційними.

Практика застосування агітаційних плакатів набула широкого поширення серед країн учасників Великої війни, плакат був основним інструментом для широкого поширення 
інформації під час війни. Країни по обидві сторони конфлікту використовували плакати, щоб заручитися підтримкою населення та підняття морального духу. Багато плакатів закликали чоловіків виконати свій обов'язок і приєднатися до армї.

У країнах, де не було гострої проблеми із комплектації військ, завдяки існуючому механізму призову та мобілізації (Франція, Німеччина, Австро-Угорщина, Російська імперія), більшість плакатів були спрямовані на збір грошей для фінансування війни. Тих, хто не вступив до військової служби, просили зробити свій внесок, купивши облігації або підписавшись на військові позики (Рис.2).
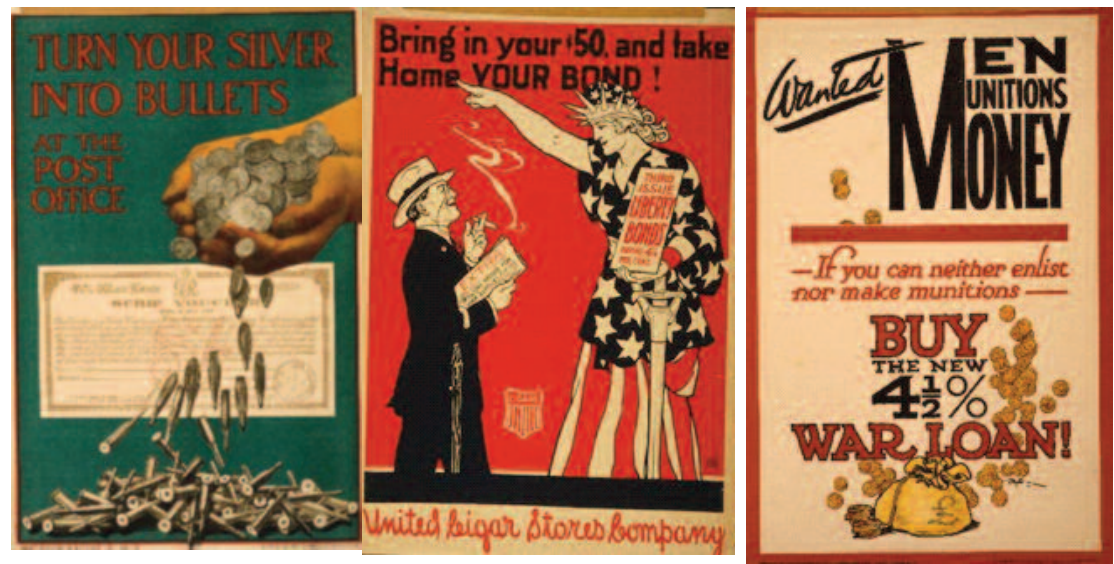

Джерело: (Posters: World War I, 1914-1918)/ 

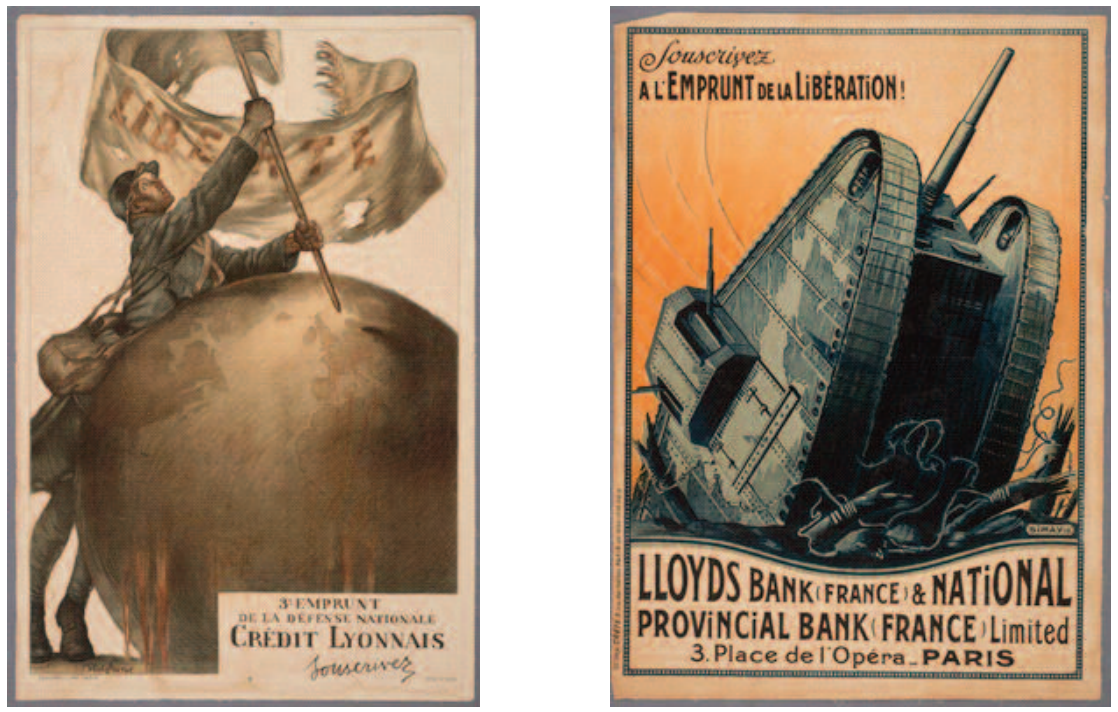

Джерело: (Browsing... 1914-1918).

\section{Рис. 2. Ахімаційні плакати щцодо популяризації серед} населення військових позик часів Периої світової війни

Як бачимо, агітаційні плакати країн учасників Великої війни (Рис.1-2) належали до типу плакатів, у яких поєднувалися шрифт i графічне зображення. Багато «фінансових» плакатів для візуалізації ідеї використовували зображення грошей, так, наприклад, монети перетворюються на кулі, що розгромлюють ворога або стають щитом під час війни.

Рекламний плакат, в Російській імперії з'явився наприкінці XIX ст., i розвивався як окремий напрямок мистецтва з урахуванням досягнень та тенденцій реклами в країнах Заходу. Тогочасні теоретики рекламної справи, досліджували засоби психологічного впливу плакатів на споживача. Так, зокрема, Теодор Кьоніг писав, що «публика оказывает наибольшее доверие тем завлекающим ее средствам, 
в частности плакатам, которые производят наилучшее, художественное впечатление» (Кёниг, 1925:21). Саме тому до виготовлення таких плакатів часто залучали відомих художників, у т. ч. й тих, які займалися розробкою російських поштових марок і паперових банкнот грошових знаків. Зокрема, художник Ріхард Заррін (латиського походження), певний час працював у відділі Експедиції заготівлі державних паперів - його плакати особливо вирізнялися лаконічністю та патріотичністю написів на кшталт: «Патриотично и выгодно!», «Всё для войны. Всё для победы.», «Отечество нуждается в Вашей помощи» тощо.

На деяких плакатах художники зазначали свої надруковані прізвища або ж увіковічнювали копії своїх підписів - Максимов А. О., Чепцов Е. М., Еберлінг А. Р., Владіміров I. тощо. Для посилення ефекту візуалізації проблеми більшість зображень на плакатах і листівках були у реалістичному стилі на кшталт: робітник (робітниця) виточує на станку снаряд, вантажні автомобілі або поїзди завантажені ящиками зі снарядами (гарматами) їдуть на фронт, військові заряджають гармату або кулемет і готуються до пострілу або ж вже стріляють тощо. Художники, які обирали національноромантичний стиль зображали: орлів (які мали місце на гербах як Російської імперії так і Австро-Угорської імперії та Німеччини) у боротьбі, де двоголовий орел (російський) перемагає одноголового (австрійського чи німецького); московських національних героїв Мініна і Пожарського на тлі імперського орла; образи Д. Донського або Г. Побєдоносця у бойових прагненнях тощо.

Усього в Російській імперії за період 1914 - 1916 років було випущено шість внутрішніх державних позик на суму 8 млрд. руб.: у 1914 році - одна позика на суму 500 млн. руб., у 1915 р. - три позики на загальну суму 2,5 млрд. руб., у 1916 р. дві позики на суму 5,0 млрд. руб.. Процес організації продажу облігацій державних військових позик координувався Державним банком Російської імперії. Він централізовано 
розсилав відповідні агітаційні плакати своїм конторам та відділенням, а також казначействам з вимогою розміщення їх у доступних для ознайомлення місцях, а також зобов'язував направити їх до громадських установ, міських громадських банків, ощадних кас, товариств взаємного кредиту та закладів дрібного кредиту та сприяти публікації оголошень у місцевих газетах (Орлик, 2016:90). У 1916 р. розробку плакатів було доручено Управлінню у справах дрібного кредиту, про що зазначалося у нижній частині плакатів дрібними буквами («Издание Управления по делам мелкого кредита. Склад издания в редакции «Вестник мелкого кредита», Петроград, Ивановская, 13. Эксп. Заг. Гос. Бум.») (див. Рис.1). Слід зазначити, що розроблені макети плакатів друкувалися у форматі листівок і мали значну популярність у населення, «їх дарували, надсилали, на них писали листи» (Бугров, 2011).

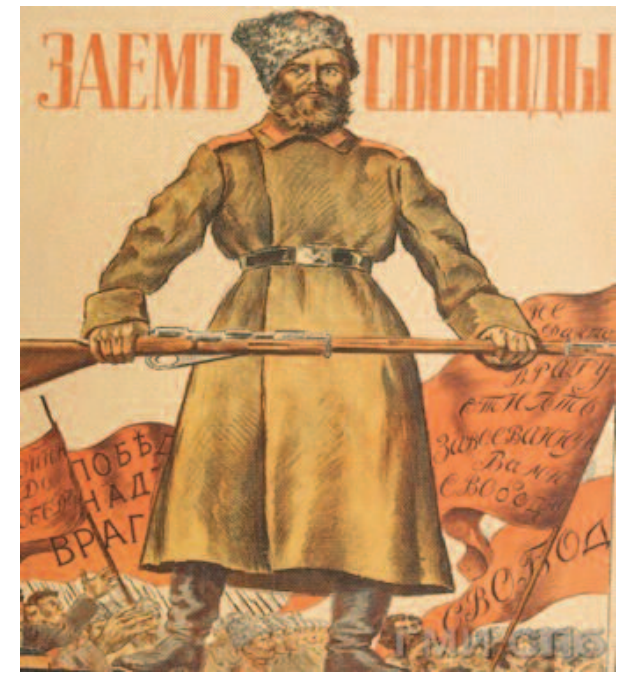

Рис. 3. Плакат «Позика Волі» 1917 р.

Що стосується військових позик Тимчасового уряду, то у березні 1917 р. прийнято відповідну Постанову Тимчасового уряду щодо випуску «Позики Волі» чотирьох серій. 
Характерною особливістю, зовнішнього вигляду цих облігацій було те, що у центральній частині облігації було розміщено звернення до громадян 3 «горячим призывом» Тимчасового уряду «одолжить деньги Государству, поместив их в новый заём, и спасём этим от гибели нашу свободу и достояние». Всього «позичити» планувалося не менше 3-х млрд. руб., за 5\% ставкою доходності, емісійним курсом 85 руб. за 100 руб. номінальної вартості зі строком погашення 49 років. Агітаційний плакат, присвячений «Позиці Волі», був розроблений відомим російським художником Борисом Кустодієвим (Рис.3). Всього за період війни для покриття військових витрат імперським урядом було випущено 6 військових внутрішніх позик на суму 8 млрд. руб. та тимчасовим урядом «Позика Волі» на суму 3 млрд. руб.

Висновок. Використання плакатного мистецтва урядом Російської імперії та Тимчасовим урядом під час проведення акцій з випуску облігацій внутрішніх позик з метою вирішення проблеми залучення фінансових ресурсів для участі у Першій світовій війні було надзвичайно актуальним та дієвим. Адже налагодження візуальної комунікації 3 потенційними покупцями (підписниками) цих облігацій засобами поширення тематичних плакатів та листівок давало можливість здійснювати результативну агітацію та пропаганду з метою формування громадської думки та спрямування суспільних дій в інтересах імперського уряду. До розробки агітаційних плакатів залучали відомих художників.

\section{ДЖЕРЕЛА ТА ЛІТЕРАТУРА}

1. Андрейканіч А. I. (2013). Плакат: його види та жанри. Українська культура: минуле, сучасне, шляхи розвитку. Вип. 19(1). С. 121-126.

2. Большакова Н. А. (2006). Фотодокументы по истории Первой мировой войны из собраний фотоальбомов РГАКФД. Вестник архивиста. №6. С. 175-189. 
3. Бугров А., Татаринов С. (2011). «Чем больше денег... тем ближе к победе»: государственный банк, искусство плаката и Первая мировая. Родина. №4. С. 84-86.

4. Волковский Н.Л. (2003). История информационных войн: в 2-х частях. СПб: Полигон. 512 с.

5. Історія інформаційно-психологічного протиборства : підруч. / Я.М.Жарков та іню; за заг. ред. Є.Д.Скулиша. К.: наук.-вид. відділ НА СБУ, 2012. 212 с.

6. Кёниг Т. (1925). Реклама и плакат как орудия пропаганды. Ленинград: Время. 285 с.

7. Кондратюк М.О. (2013). Інформаційна війна та роль масмедіа в міжнародних конфліктах. Вісник Харківської державної академії культури. Вип. 41. С. 108-113.

8. Ласвель Г. (1929). Техника пропаганды в мировой войне. Москва-Ленинград: ГИЗ, 200 с.

9. Малышева Г. Е. (2009). Исследование киноматериалов Сербии периода Первой мировой войны 1914-1918 гг. Новые проекты Российского государственного архива кинофотодокументов. Вестник архивиста. № 4. С. 21-27.

10. Михайлов И.А. (1917). Государственные доходы и расходы России во время войны. Война и экономическая жизнь: очерки и материалы для характеристики народного и государственного хозяйства в связи с войной. Петроград: тип. «Правда». Вып.V - VII. 164 с.

11. Мосієнко О.В. (2016). Внутрішня і зовнішня пропаганда Австро-Угорської та Російської імперій на Південно-Західному фронті в роки Першої світової війни. Сумський історикоархівний журнал. № 27. С. 72-80.

12. Орлик С.В. (2016). Внутрішні позики Російської імперії періоду Першої світової війни. Наукові записки з украӥнської історії: Збірник наукових статей. Вип. 38. С. 81-96.

13. Орлик С. В. (2018). Фінансова політика російського уряду на окупованих територіях Галичини і Буковини в період Першої світової війни (1914-1917 рр.). Біла Церква: Видавець Пшонківський О.В. 617 с. 
14. Орлик С.В. (2020). Пропаганда облігацій військових позик в Російській імперії на шпальтах газети «Киевлянин» (1916 р.). Соціум. Документ. Комунікація. Серія «Історичні науки». Вип. 9. С.180-199. DOI: 10.31470/2518-7600-2020-9180-199.

15. Подписка на военный заём 1916 года. Киевлянин. 1916. №80 (20 марта). С.2.

16. Скрипник П. (2021). Плакати як джерело дослідження соціально-політичних процесів в Україні у 20-х роках XX ст. Наукові праці Національної бібліотеки України імені В. І. Вернадського. Вип. 60. С. 109-126.

17. Цыкалов Д. Е. (2012). Карикатура как орудие пропаганды в период Первой мировой войны. Вестник Волгоградского государственного университета. Сер. 4, История. Регионоведение. Международные отночения. №1 (21). C. 85-90.

18. Browsing items in: World War I Posters Collection. Harry Ransom Center - the University of Texas at Austin. URL: https:/hrc.contentdm.oclc.org/digital/collection/p15878coll26/searc $\mathrm{h}$

19. Goldstein J.S. (2001). War and gender: How gender shapes the war system and vice versa. Cambridge: Cambridge University Press.

20. Lasswell H. (1927). Propaganda technique in the World War. London.

21. Posters: World War I Posters. Library of Congress. URL: http://surl.li/axbrk

22. Stuart C. (1920). Secrets of Crewe House. The Story of a Famous Campaign. - Hodder and Stoghton, London.

\section{REFERENCES}

1. Andreikanich, A. I. (2013). Plakat: yoho vydy ta zhanry [Poster: its types and genres]. Ukrainska kultura: mynule, suchasne, shliakhy rozvytku - Ukrainian culture: past, present, ways of development, 19(1), 121-126 [in Ukrainian].. 
2. Bol'shakova, N. A. (2006). Fotodokumenty po istorii Pervoy mirovoy voyny iz sobraniy fotoal'bomov RGAKFD [Photo documents on the history of the First World War from the collections of the RSAKFD photo albums]. Vestnik arkhivista Archivist's bulletin, 6, 175-189[in Russian].

3. Bugrov, A. \& Tatarinov, S. (2011). "Chem bol'she deneg...tem blizhe k pobede": gosudarstvennyj bank, iskusstvo plakata i Pervaja mirovaja ["The more money ... - the closer to victory": the state bank, the art of poster and the First World War]. Rodina Homeland, 4, 84-86 [in Russian].

4. Volkovskij, N.L. (2003). Istorija informacionnyh vojn: v 2-h chastjah [The history of information wars: in 2 parts.]. SPb: Poligon [in Russian].

5. Istoriia informatsiino-psykholohichnoho protyborstva [History of information and psychological confrontation] (2012). / Ya.M.Zharkov ta in.; za zah. red. Ye.D.Skulysha. K.: nauk.-vyd. viddil NA SBU [in Ukrainian].

6. Kyonig, T. (1925). Reklama i plakat kak orudiya propagandy [Advertisements and posters as instruments of propaganda]. Leningrad: Vremya [in Russian].

7. Kondratyuk, M.O. (2013). Informatsiyna viyna ta rol' masmedia $\mathrm{v}$ mizhnarodnykh konfliktakh [Information warfare and the role of mass media in international conflicts]. Visnyk Kharkivs 'koyi derzhavnoyi akademiyi kul'tury - Bulletin of the Kharkiv State Academy of Culture, 41, 108-113 [in Ukrainian].

8. Lasvel', G. (1929). Tehnika propagandy v mirovoj vojne [World War Propaganda Technique]. Moskva-Leningrad: GIZ [in Russian].

9. Malysheva, G. Ye. (2009). Issledovaniye kinomaterialov Serbii perioda Pervoy mirovoy voyny 1914-1918 gg. Novyye proyekty Rossiyskogo gosudarstvennogo arkhiva kinofotodokumentov [A study of Serbian film materials during the First World War 1914-1918. New projects of the Russian State Archive of Film and Photo Documents]. Vestnik arkhivista Archivist's bulletin, 4, 21-27[in Russian]. 
10. Mikhaylov, I.A. (1917). Gosudarstvennyye dokhody i raskhody Rossii vo vremya voyny [State revenues and expenditures of Russia during the war]. Voyna i ekonomicheskaya zhizn': ocherki $i$ materialy dlya kharakteristiki narodnogo i gosudarstvennogo khozyaystva v svyazi s voynoy. Petrograd: tip. «Pravda», V - VII [in Russian].

11. Mosiienko, O.V. (2016). Vnutrishnia i zovnishnia propahanda Avstro-Uhorskoi ta Rosiiskoi imperii na Pivdenno-Zakhidnomu fronti $v$ roky Pershoi svitovoi viiny[Internal and external propaganda of the Austro-Hungarian and Russian empires on the South-Western Front during the First World War]. Sumskyi istorykoarkhivnyi zhurnal - Sumy historical and archival journal, 27, 72-80 [in Ukrainian].

12. Orlyk, S. (2016). Vnutrishni pozyky Rosiiskoi Imperii periodu Pershoi svitovoi viiny [Domestic Borrowings of the Russian Empire during the First World War]. Naukovi zapysky z ukrainskoi istorii - Scientific notes on Ukrainian history, (38), 8196 [in Ukrainian].

13. Orlyk, S. V. (2018). Finansova polityka rosiiskoho uriadu na okupovanykh terytoriiakh Halychyny i Bukovyny v period Pershoi svitovoi viiny (1914 - 1917 rr.) [Financial policy of the Russian government in the occupied territories of Galicia and Bukovina during the First World War (1914 - 1917)]. Belaya Tserkov: vydavets Pshonkovsky O. V. [in Ukrainian].

14. Orlyk, S. V. (2020). Propahanda oblihatsii viiskovykh pozyk v Rosiiskii imperii na shpaltakh hazety «Kievlianin» (1916 r.) [Propaganda of war loan bonds in the russian empire on the pages of the «Kievlyanin» newspaper (1916)]. Sotsium. Dokument. Komunikatsiia. Seriia "Istorychni nauky»-Society. Document. Communication. Series «Historical Sciences», 9, 180-199 [in Ukrainian].

15. Podpiska na voyennyy zayom 1916 goda. (1916). Kiyevlyanin, 80 (March 20), 2 [in Russian].

16. Skrypnyk, P. (2021). Plakaty yak dzherelo doslidzhennia sotsialno-politychnykh protsesiv v Ukraini u 20-kh rokakh XX st 
[Printed Posters as a Source for the Study of the Social and Political Processes in Ukraine in the 1920-ies]. Naukovi pratsi Natsionalnoi biblioteky Ukrainy imeni V. I. Vernadskoho - Scientific works of the National Library of Ukraine named after V.I. Vernadsky, 60, 109-126[in Ukrainian].

17. Tsykalov, D. Ye. (2012). Karikatura kak orudiye propagandy $\mathrm{v}$ period Pervoy mirovoy voyny. Vestnik Volgogradskogo gosudarstvennogo universiteta. Ser. Istoriya. Regionovedeniye. Mezhdunarodnyye otnosheniya - Bulletin of the Volgograd State University. Series History. Regional studies. International relationships, 1 (21), 85-90[in Russian].

18. Browsing items in: World War I Posters Collection. Harry Ransom Center - the University of Texas at Austin. URL: https://hrc.contentdm.oclc.org/digital/collection/p15878coll26/searc $\mathrm{h}$ [in English].

19. Goldstein, J.S. (2001). War and gender: How gender shapes the war system and vice versa. Cambridge: Cambridge University Press [in English].

20. Lasswell, H. (1927). Propaganda technique in the World War. London [in English].

21. Posters: World War I Posters. Library of Congress. URL: http://surl.li/axbrk [in English].

22. Stuart, C. (1920). Secrets of Crewe House. The Story of a Famous Campaign. - Hodder and Stoghton, London [in English].

\section{АНОТАЦІЯ}

У статті розглянуто застосування наглядних агітаційних матеріалів у вигляді плакатів та листівок, які створювалися та поширювалися серед населення з метою проведення агітаиії та пропаганди облігаџій військових позик у Російській імперії в роки Першої світової війни.

Звернута увага на те, щуо у часи Першої світової війни поліграфічна продукція та періодична преса були основними засобами пропагандистського впливу, адже кіно і радіо ще не набули широкого поширення. Проте саме випуск плакатів $i$ 
листівок були на той час одним з найдієвіших способів спрямованого і комплексного впливу на адресата, оскільки в них використовуються вербальні ц̌ невербальні елементи, щзо становлять єдину візуальну, змістовну, структурну, та функиіональну иүілісність.

Акиентовано увагу на тому, щзо практика застосування агітаційних плакатів мала широке використання не лише в Російській імперії, а й серед інших краӥн учасників Великої війни (Франції, Німеччини, Австро-Угорщиини тощуо), які також здійснювали випуск облігаџій внутрішніх державних позик у своїх краӥнах.

У результаті проведеного аналізу зображень $і$ текстів на плакатах, які стосувалися тематики військових позик, встановлено, щуо вони були суто пропагандистськими та мали агітаџійне спрямування. До розробки агітаџійних плакатів залучали відомих вітчизняних художників. Переважна більшість авторів плакатів для посилення ефекту візуалізаиії проблеми обирали реалістичний або національно-романтичний стиль.

Тож, автор статті дійшов висновку, щзо використання плакатного мистецтва урядом Російської імперї та Тимчасовим урядом Росї під час проведення акцій з випуску облігацій внутрішніх позик з метою вирішення проблеми залучення фінансових ресурсів для участі у Першій світовій війні було надзвичайно актуальним та дієвим. Адже налагодження візуальної комунікації з потенційними покупцями (підписниками) цих облігащій засобами поширення тематичних плакатів та листівок давало можливість здійснювати результативну агітацію та пропаганду з метою формування громадської думки та спрямування суспільних дій в інтересах уряду.

Ключові слова: Перша світова війна, Російська імперія, пропаганда, агітаџія, військові позики, облігаџія, плакати, листівки. 


\section{АННОТАЦИЯ}

B cтатье рассмотрено применение наглядных агитационных материалов в виде плакатов и открыток, которые создавались и распространялись среди населения с цеелью проведения агитацчи и пропаганды облигачий военных займов в Российской империи в годы Первой мировой войны.

Обращено внимание на то, что во времена Первой мировой войны полиграфическая продукиия и периодическая печать были основными средствами пропагандистского воздействия, ведь кино и радио ещче не получили широкого распространения. Однако, именно выпуск плакатов $и$ открыток были в то время одними из самых действенных способов направленного и комплексного воздействия на адресата, поскольку в них используются вербальные и невербальные элементы, составляющие единую визуальную, содержательную, структурную и функциональную изелостность.

Акиентировано внимание на том, что практика применения агитационных плакатов имела широкое применение не только в Российской империи, но и среди других стран участников Великой войны (Франции, Германии, Австро-Венгрии и т. д.), которые также осущуествляли выпуск облигаций внутренних государственных займов в своих странах.

В результате проведенного анализа изображений $u$ текстов на плакатах, касающиеся тематики военных займов, установлено, что они были чисто пропагандистскими и имели агитационное направление. $K$ разработке агитационных плакатов привлекались известные отечественные художники. Подавляющее большинство авторов плакатов для усиления эффекта визуализации проблемы выбирали реалистичный или национально-романтический стиль.

Таким образом, автор статьи пришел квыводу, что использование плакатного искусства правительством Российской империи и Временным правительством России во 
время проведения акциий по выпуску государственных облигаций внутренних займов с иелью решения проблемь привлечения финансовых ресурсов для участия в Первой мировой войне было чрезвычайно актуальным и действеннылм. Ведь налаживание визуальной коммуникаџии с потенциальными подписчиками этих облигаций средствами распространения тематических плакатов и листовок предоставляло возможность осуществлять результативную агитаџию и пропаганду с изелью формирования общественного мнения и направления общественных действий в интересах правительства.

Ключевые слова: Первая мировая война, Российская империя, пропаганда, агитаџия, военные займы, облигачия, плакаты, открытки. 